\title{
PENDIDIKAN AGAMA ISLAM DAN PENANGGULANGAN KENAKALAN SISWA (Studi Kasus MTs Hasanah Surabaya)
}

\author{
Muchammad Ainul Yaqin \\ (MTs Hasanah Surabaya)
}

\begin{abstract}
Abstrak:
Dalam tulisan ini penulis meneliti tentang jenis kenakalan siswa, faktorfaktor yang mempengaruhinya dan bagaimana usaha sekolah dalam menanggulanginya melalui internalisasi Pendidikan Agama Islam. Dari data yang diperoleh, penulis memberikan kesimpulan bahwasannya keadaan nyata kenakalan siswa MTs Hasanah masih tergolong biasa dan tidak berbahaya seperti membolos, terlambat datang ke sekolah, tidak mengerjakan PR, membuat gaduh dan sebagainya. Faktor-faktor yang mempengaruhi kenakalan siswa sering kali disebabkan karena kurangnya perhatian orang tua (broken home), pengaruh teman sepermainan dan dari diri mereka sendiri karena malas dan takut dengan guru. Sebagai upaya usaha pihak sekolah dalam menanggulangi kenakalan siswa dengan tiga cara yaitu secara preventif, represif dan kuratif. Preventif yang dianggap cukup berhasil adalah mengadakan pendekatan dengan orang tua atau wali siswa. Sedangkan cara represif yang cukup berhasil adalah dengan pemberian hukuman yang mendidik. Cara kuratif yang dianggap cukup berhasil adalah tradisi silaturrahim ke rumah siswa dengan diiringi kegiatan kegamaan dan penanaman nilai-nilai keteladanan.
\end{abstract}

Kata Kunci: Pendidikan Agama Islam, Kenakalan Siswa, Reinternalisasi, Keteladanan. 


\begin{abstract}
:
This paper deals with juvenile delinquency in many types, the antecedent factors, and how the school deals with the problem through Islamic Education as a school subject. The findings show that the delinquency level in the madrasah is still in the common level, and not dangerous, such as skipping classes, coming late to school, skipping homeworks, convulsing behaviors, etch. Several factors causing the behaviors are deserving parents' attention (due to broken home), influence of peer friends, laziness, and being uncomfortable with teacher presence. The school deals with the problems mainly in three ways: preventive, repressive, and curative. The prevention is considered more fruitful due to the school approaches to the parents or those responsible to the students at home. Educative punishment is considered successful enough. Last, the curative also takes effect enough through the silaturrahim tradition along with religious activities and inserting values through personal modelling.
\end{abstract}

\title{
Keywords: Islamic Education, Juvenile Delinquency, Reinternalization, Personal Modelling.
}

\section{A. Pendahuluan}

Akhir-akhir ini banyak penilaian orang terhadap generasi muda, bukan hanya dari media masa saja akan tetapi dalam perbincangan sehari-hari. Sikap anarkis siswa sudah sering membuat pusing berbagai pihak, tingkat kebrutalan siswa Indonesia telah mencapai tingkat kriminal yang tinggi, siapakah yang bertanggung jawab akan problematika ini. Pada era globalisasi, masalah siswa dengan tindakan negatifnya perlu mendapatkan perhatian khusus dari berbagai pihak, terutama orang tua serta guru-guru selaku pembimbing, pengarah sekaligus panutan. Siswa merupakan generasi penerus perjuangan bangsa, apabila generasi mudanya rusak maka rusaklah masa depan suatu negara dan agama.

Masih siswa sudah merokok, mabuk, nyabu, tawuran, bahkan free seks. Seram memang, namun itulah potret siswa yang ada di kota Surabaya sekarang. Kebanyakan malah menaganggapnya sudah tidak tabu. Semua bentuk kenakalan itu merupakan bagian dari perilaku menyimpang yang kerap akan merugikan mereka sendiri. Sebagai orang tua, wajib hukumnya mengerti dan peduli.Para ahli pendidikan sependapat bahwa siswa adalah mereka yang berusia 13-18 tahun. Pada usia tersebut, seseorang sudah melampaui masa kanak-kanak, namun masih belum cukup matang untuk dapat dikatakan dewasa. Ia berada pada masa transisi. Karena transisi itulah yang kerap banyak godaan untuk menuju matang. 1

Kenakalan remaja, Surabaya, http://surabaya-metropolis.com/serba-kota/gayahidup/kenakalan-remaja-gaya-hidup-menyimpang.html. Diakses pada 20 November 2016. 
Sebagaimana telah diketahui dari berbagai macam media masa; baik televisi, radio atau Koran, kriminalitas siswa semakin merajalela mulai dari perkelahian masal (tawuran), pemerkosaan, perusakan sarana pemerintah sampai kepada suatu tingkat yang lebih biadab yaitu pembunuhan, diantara faktor-faktor utama yang menyebabkan penyimpangan (anomali) siswa serta mendorongnya untuk terjerumus kepada perbuatan dosa adalah karena seringnya menyaksikan film-film (adegan) kriminal dan pornografi ditelevisi dan dibioskop atau melalui media masa yang lainnya seperti majalah dan novel yang cabul. ${ }^{2}$

Semua ini mampu memberikan stimulisisasi (rangsangan) kepada para siswa untuk melakukan penyimpangan dan kejahatan, hal itu juga berdampak pada kerusakan akhlakul karimah orang dewasa, maka apakah yang akan terjadi bila hal itu dilakukan oleh para siswa dan anak-anak kecil, dengan melalui dasardasar pendidikan islam dan meletakkan metode yang benar dalam memberikan pengarahan serta bimbingan anak, melaksanakan hak dan kewajibannya di hadapan orang tua, pendidik dan penanggung jawab.

Sebagian di antara dasar-dasar metode ini ialah tindakan preventif yang mutlak dari setiap yang menyebabkan datangnya murka Allah dan dimasukkan kedalam neraka Allah SWT berfirman dalam al-Quran :

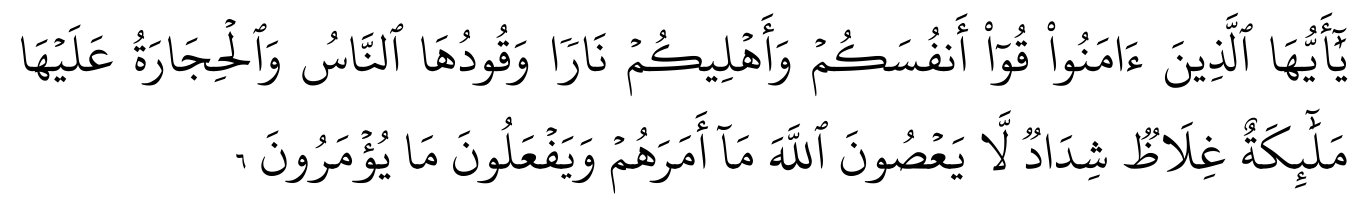

"Hai orang-orang yang beriman, perihalah dirimu dan keluargamu dari api neraka yang bahan bakarnya adalah manusia dan batu, penjaganya malaikat yang kasar, yang keras, yang tidak mendurhakai Allah terhadap apa yang diperintahkannya kepada mereka serta selalu mengerjakan apa yang diperintahkannya".3 (QS.At- Tahrim: 6)

Pendidikan mempunyai peranan penting dalam pembinaan dan pengembangan anak, terutama berkenaan dengan penanaman nilai-nilai keagamaan semenjak dini. Mendidik anak merupakan tanggung jawab (responsibility) yang sangat berat, Nabi Muhammad SAW saja telah memberikan gambaran dengan tepat tentang tanggung jawab ini, yakni sebagai seorang pengembala, sebagai pengembala haruslah berhati-hati terhadap gembalanya, orang tua harus secara terus menerus mengawasi serta memperhatikan sehingga yakin bahwa anak-anak mereka tidak tersesat serta terjerumus kedalam perbuatan-perbuatan yang tercela, sebagai orang tua muslim sangatlah menghadapi tantangan yang berat dalam menjaga anak-anak mereka agar tumbuh

2 Safari Soma, Menanggulangi Remaja Kriminal, Islam Sebagai Alternatif (Bogor : Bintang Tsurayya, 1995), I.

3 Mahmud Yunus, Al-Qur"An Dan Terjemahannya (Bandung: Al-Maarif, 1990), cet. 9, 448. 
sesuai dengan ajaran al-Qur'an maupun hadits (sunnah). Apabila hal tersebut mampu dilakukan maka selamatlah anak-anak mereka dari marah bahaya, sebagaimana yang termaktub dalam ayat-ayat Al-Qur'an.

Pendidikan merupakan bagian yang tidak dapat dipisahkan dari hidup dan kehidupan manusia, begitu pula dengan proses perkembangannya. Bahkan keduanya saling mempengaruhi dan merupakan proses yang satu. Manusia sangat membutuhkan pendidikan dalam menjalani kehidupannya di dunia ini.

Tujuan dari pendidikan nasional Indonesia adalah untuk berkembangnya potensi peserta didik agar menjadi manusia yang beriman dan bertakwa kepada Tuhan Yang Maha Esa, berakhlak mulia, sehat, berilmu, cakap, kreatif, mandiri dan menjadi warga Negara yang demokratis serta bertanggung jawab. ${ }^{3}$ Dalam Pendidikan Islam tujuan pokok dan terutama adalah mendidik budi pekerti dan pendidikan jiwa. ${ }^{4}$ Al-Ghazali, juga menyatakan tujuan dari pendidikan adalah taqarrub kepada Allah dan kesempurnaan manusia untuk mencapai kebahagiaan dunia dan akhirat. ${ }^{5}$ Dari tujuan pendidikan diatas bisa dikatakan bahwa tujuan pendidikan nasional dari waktu ke waktu selalu bermuara pada terbentuknya manusia yang susila atau berbudi pekerti luhur.

Siswa di sekolah menengah mempunyai tingkat perkembangan kepribadian dan sosial yang berada dimana pada masa transisi dari anakanak ke siswa. Masa siswa di sekolah menengah menghadapi beberapa aspek utama perkembangan kejiwaan anak yaitu berkaitan dengan status sosial dan keragaman kemampuan kognisi yang akan mempengaruhi proses pendidikan di sekolah. Latar belakang sosial seperti keluarga, ekonomi masing-masing anak yang berbeda akan memberikan pengaruh pada prestasi anak di sekolah.

Dengan kondisi perkembangan siswa pada masa ini maka proses pendidikan memerlukan kondisi kondusif agar perkembangan kemampuan kognitif, afektif dan psikomotorik siswa dapat mencapai tujuan yang diharapkan. Generasi muda adalah sebagai generasi penerus yang akan menggantikan estafet generasi orang tua, sudah barang tentu harus dibina dengan sungguh-sungguh agar mereka menjadi generasi penerus yang bertanggung jawab dan bermoral.

Kewajiban untuk membina tidak cukup diserahkan kepada guru saja, tetapi keluarga dan lingkungan masyarakat juga mempunyai peranan yang sama. Sebagaimana telah sama-sama diketahui, bahwa paling tidak terdapat tiga lingkungan pendidikan yang berpengaruh terhadap pembentukan kualitas dan

\footnotetext{
3 UUSPN Nomor 20 Tahun 2003, BAB II,Pasal 3.

4 M.Athiyah al-Abrasyi, Dasar-Dasar Pokok Pendidikan Islam (Jakarta: Bulan Bintang, 1993), 1.

5 M. Djunaidi Ghony, "Pemikiran Al-Ghazali Tentang Pendidikan" (Jurnal el-hikmah, Fakultas Tarbiyah UIN Malang. No.2 th.III Januari 2006), 186.
} 
kepribadian siswa, yakni lingkungan keluarga, sekolah dan masyarakat. ${ }^{6}$ Yang ideal adalah terjadi kondisi yang harmonis dan sinergis di antara ketiganya dan merupakan satu kesatuan yang terintegrasi. Apa yang diyakini baik dirumah, baik pula di sekolah dan masyarakat. Demikian pula hanya ketidakbaikan, semuanya memberikan persepsi dan perlakuan yang sama. Tetapi dalam kenyataannya tidaklah selalu demikian.

Betapa banyak kontradiksi dan pertentangan antara yang satu dengan yang lainnya. Di rumah sesuatu yang diyakini sebagai hal yang buruk dan tidak boleh dilakukan, tetapi ternyata dengan leluasanya di masyarakat hal itu dilihat siswa dilakukan oleh orang-orang. Demikian pula dalam dunia pendidikan kita telah terjadi krisis panutan (figur) yang bisa dijadikan contoh bagi para siswa. Disamping itu, pendidikan agama masih terpisah dengan pendidikan umum. Padahal, seharusnya menjadi satu kesatuan yang terintegrasi. Hal ini semuanya sering mengakibatkan kebingungan bagi siswa, sekaligus terpecahnya kepribadian.

Dewasa ini, bangsa Indonesia dihadapkan pada berbagai persoalan yang berat dan kompleks. ${ }^{7}$ Perbaikan ekonomi yang dilakukan pemerintah belum menunjukkkan titik terang, bahkan ada kecenderungan kondisinya semakin merosot. Pada sisi akhlak dan moral, tampak menguat fenomena kerusakan akhlak yang sangat mencemaskan. Pergaulan bebas dan perzinaan merebak bagaikan jamur di musim hujan, di kota-kota maupun daerah-daerah. Peredaran video porno merajalela ke berbagai tempat, bahkan di dekat kompleks pendidikan. Pemakaian obat-obat terlarang juga semakin memprihatinkan. Kini, obat perusak masa depan ini, masuk ke berbagai kalangan. Dari kalangan olahragawan hingga anak-anak usia SD.

Dampak krisis sosial yang melanda saat ini adalah krisis nilai-nilai moral. Sementara pendidikan sebagai agen penanaman nilai, moral dan budaya, belum mencerminkan kearah yang sebenarnya. Akibatnya, ikatan moral menjadi semakin longgar dan tata nilai positif menjadi nisbi. Selain itu, pembiayaan hidup yang semakin besar karena keperluan semakin bertambah, maka tidaklah terlalu mengherankan kalau dalam masyarakat yang sedang mangalami perkembangan seperti di Indonesia mempunyai bermacam-macam permasalahan termasuk diantaranya adalah permasalahan yang dialami oleh siswa, karena pada masa ini merupakan masa yang khusus, penuh gejolak karena pada pertumbuhan fisik terjadi ketidakseimbangan. Hal ini akan mempengaruhi perkembangan berpikir, bahasa, emosi dan sosial siswa. ${ }^{8}$ Oleh karenanya masalah siswa adalah suatu

\footnotetext{
${ }^{6}$ Didin Hafidhuddin, Membentuk Pribadi Qur'ani (Bandung : Harakah, 2002), 246.

${ }^{7}$ Hafidhuddin, Membentuk Pribadi Qur'ani, 75.

8 Sunarto. Perkembangan Peserta Didik (Jakarta: Rineka Cipta, 1999), 75.
} 
masalah yang sangat menarik untuk dibicarakan, lebih-lebih pada akhir-akhir ini di mana telah timbul akibat negatif yang akan membawa kehancuran bagi siswa itu sendiri dan masyarakat pada umumnya.

Mengingat betapa pentingnya kehidupan siswa sebagai remaja terhadap kehidupan dan masa depan bangsa dan negara. Maka penulis merasa terdorong untuk melakukan studi untuk penelitian di MTs Hasanah Surabaya ${ }^{9}$ guna melihat lebih dekat terhadap kehidupan siswa yang bermasalah, dengan solusi alternatif melalui pendidikan agama Islam di lembaga tersebut.

\section{B. Agama dan Siswa; Spiritualitas dalam Pendidikan}

Agama merupakan bagian yang sangat penting dalam jiwa seseorang. Agama bisa merupakan salah satu faktor pengendali terhadap tingkah laku atau sesuatu yang dapat menstabilkan tingkah laku dan bisa menerangkan mengapa dan untuk apa seseorang berada di dunia ini. Belakangan ini banyak didengar berbagai keluhan orang tua, guru dan orang-orang yang berkecimpung dalam bidang agama dan sosial, karena anak-anak terutama yang sedang sulit dikendalikan, nakal, keras kepala, berbuat onar, maksiat dan hal-hal yang mengganggu ketenteraman umum. Salah satu sebabnya adalah dikarenakan oleh kurangnya pemahaman terhadap agamanya. Gejala kemerosotan moral yang terjadi yang terpenting diantaranya adalah kurang tertanamnya jiwa agama dalam tiap-tiap individu dan tidak dilaksanakannya ajaran agama dalam kehidupannya sehari-hari, baik individu atau oleh kelompok masyarakat.

Pada dasarnya perasaan keagamaan secara potensial sudah terdapat dalam setiap individu manusia. Hanya saja cara perkembangannya dan pemikirannya untuk menyampaikan kepada mereka tentang Dzat Yang Maha Kuasa itu berbedabeda menurut tingkat kehidupan dan pendidikan yang menyebabkan mereka menyimpang dari ajaran agama itu atau menyimpang dari fitnah agamanya.

Allah dalam al-Qur'an telah berfirman:

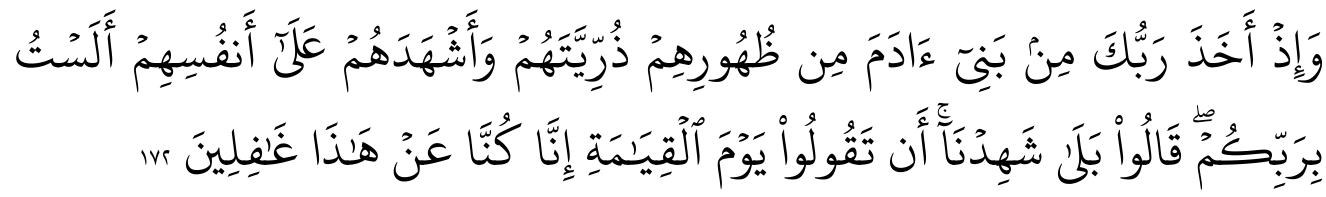

"Dan (ingat) ketika Tuhanmu mengambil janji (sewaktu) menjadikan keturunan anak Adam dari tulang punggungnya di alam zuhriah dan memberikan kesaksian atas pribadi-pribadinya, Allah berkata: "Apakah Allah Tuhanmu..? mereka menjawab:

${ }^{9}$ MTs Hasanah Surabaya adalah sebuah institusi pendidikan yang berada di bawah Yayasan Pendidikan Islam Hasanah yang didirikan pada tahun 1984, dan mulai beroperasi pada tahun 2007. Madrasah ini beralamatkan di jalan Kapas Madya IE / 64, kecamatan Tambaksari, Surabaya. Luas wilayah MTS Hasanah adalah 400 m2, dengan luas bangunan 290 m2. 
"Betul Tuhanku, kami mengakui (bahwa Engkau Tuhan kami), "supaya kamu jangan mengatakan pada hari kiamat nanti: "sesungguhnya kami lengah daripada ini" (QS. AlA'raf 172)

Dari ayat tersebut dapat dipahami bahwa manusia di alam roh yang merupakan calon penghuni dunia, maka disana telah berikrar (mengakui) bahwa Allah adalah Tuhan. Hal ini berarti bahwa manusia secara fitrah mengakui agama tauhid, agama fitrah yaitu Islam.

Firman Allah SWT:

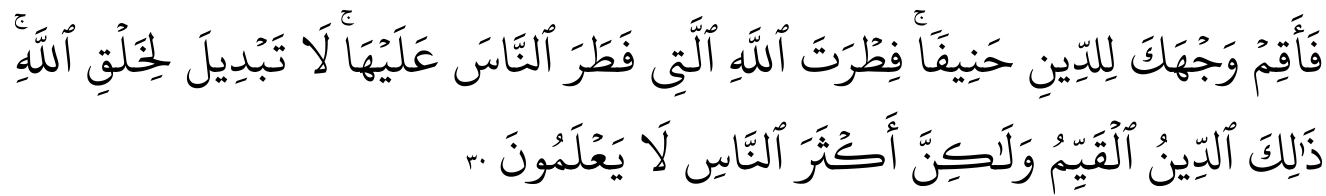

"Maka hadapkanlah wajahmu dengan lurus ke agama (Allah yaitu islam) dan (tetaplah atas) fitrah (yang mana) Allah telah menciptakan manusia fitrahnya itu. Tidak ada perubahan pada fitrah Allah. (Itulah) agama yang lurus, tetapi kebanyakan manusia tidak mengetahuinya". (QS. Ar-Rum : 30)

Secara potensial memang setiap individu (anak) dilahirkan membawa fitrah agama, namun potensi yang dimiliki tersebut tanpa adanya dukungan atau pengaruh dari luar atau lingkungan dimana ia tinggal, keluarga, sekolah dan masyarakat, maka jauh kemungkinannya bisa berkembang sebagaimana semestinya. Sebagaimana dikemukakan oleh Zakiyah Darajat: "perkembangan agama pada masa anak, terjadi melalui pengalaman hidupnya sejak lahir, dalam keluarga, di sekolah dan di masyarakat. Semakin banyak pengalaman bersifat agama, tindakan, kelakuan dan cara menghadapi hidup akan sesuai dengan ajaran agama".10

Pengalaman agama yang dilalui oleh anak di waktu kecilnya merupakan unsur penting dalam kehidupan keagamaan di masa mendatang (masa siswa dan dewasa). Hal ini sesuai dengan pendapat Sutikno, bahwa pengenalan terhadap agama sejak dini diperlukan oleh anak didik agar mempunyai kepribadian susuai dengan unsur moralitas yang ada di dalam agama. ${ }^{11}$ Seorang yang pada waktu kecilnya tidak pernah mendapatkan pendidikan agama, maka pada masa dewasanya nanti tidak akan merasakan pentingnya agama dalam kehidupannya atau bahkan mungkin kurang perduli terhadap agama. Lain halnya dengan seorang yang sejak kecil sudah banyak mendapatkan pendidikan agama atau telah ada pengaruh lingkungan untuk mengembangkan potensi keagamaannya, maka setelah siswa atau dewasa mempunyai kecenderungan kepada hidup yang selalu dilandasi oleh nilai-nilai ajaran agama yang dianutnya.

10 Darajat, Membina Nilai-Nilai Moral Di Indonesia, 55.

11 Sutikno, "Pola Pendidikan Islam dalam Surat Luqman Ayat 12-19" Jurnal Pendidikan Agama Islam (JPAI) FTK UIN Sunan Ampel Surabaya, Vol. 1. No. 2 (2013), 292. 
Perkembangan keagamaan seseorang sejalan dengan perkembangan kecerdasan yang dilaluinya. Pada usia anak sesuai dengan tingkat kecerdasannya belum memungkinkan untuk berfikir logis dan juga belum dapat memahami halhal yang abstrak, maka apapun yang dikatakan kepadanya akan diterima begitu saja. Pada masa remaja, perkembangan kecerdasan siswa telah mencapai titik kesempurnaan ia telah mampu memahami hal-hal yang abstrak serta juga telah mampu mengambil suatu kesimpulan dari apa yang dilihatnya. ${ }^{12}$

Kadang-kadang mengalami atau menemukan suatu ketenangan. Tapi kadang-kadang juga mengalami suatu kegelisahan. Apalagi bila ia melihat perbedaan atau kesenjangan antara apa yang ia terima dengan perilaku orang dalam kehidupan masyarakat. Susunan kejiwaan seperti ini bisa mempengaruhi perasaan atau keyakinan keagamaan siswa. Keyakinan siswa terhadap agama mengalami ambivalen atau keyakinan yang maju mundur. Ia sangat membutuhkan pertolongan, rajin beribadah kepada Allah sewaktu mengalami suatu kegelisahan atau menuntut suatu keberhasilan, tetapi setelah mengalami ketenangan atau keberhasilan tercapai ia melupakan ketergantungannya kepada Allah. Bahkan bisa berkembang menjadi conversi (meninggalkan agama).

Oleh karena itu, melalui proses belajar-mengajar pendidikan agama diharapkan terjadinya perubahan dalam diri anak baik aspek kognitif, afektif maupun psikomotor. Dan dengan adanya perubahan dalam tiga aspek tersebut diharapkan akan berpengaruh terhadap tingkah laku anak didik, di mana pada akhirnya cara berfikir, merasa dan melakukan sesuatu itu akan menjadi relatif menetap dan membentuk kebiasaan bertingkah laku pada dirinya, perubahan yang terjadi harus merupakan perubahan tingkah laku yang mengarah ke tingkah laku yang lebih baik.

Di samping pendidikan agama disampaikan secara empirik problematik, juga disampaikan dengan pola homeostatika yaitu keselarasan antara akal kecerdasan dan perasaan yang melahirkan perilaku akhlakul karimah dalam kehidupan berbangsa dan bernegara. Pola ini menuntut upaya lebih menekankan pada faktor kemampuan berfikir dan berperasaan moralis yang merentang kearah Tuhannya, dan kearah masyarakatnya, di mana iman dan taqwa menjadi rujukannya. Pendidikan agama Islam memiliki beban yang multi paradigma, sebab berusaha memadukan unsur profan dan imanen, dimana dengan pemaduan ini, akan membuka kemungkinan terwujudnya tujuan inti pendidikan Islam yaitu

12 Perkembangan kecerdasan siswa telah mencapai pada titik kesempurnaan, namun kemampuan untuk menggunakannya kecerdasan itu dengan baik dan optimal masih kurang. Hal ini dikarenakan masa siswa masih dipengaruhi oleh perasaan emosi yang belum stabil. Perasaan emosi siswa selalu mengalami perubahan. 
melahirkan manusia-manusia yang beriman dan berilmu pengetahuan, yang satu sama lainnya saling menunjang. Disamping itu, Pendidikan agama Islam memberikan bimbingan jasmani-rohani berdasarkan hukum-hukum agama Islam menuju terbentuknya kepribadian utama menurut ukuran-ukuran Islam. ${ }^{13}$

Pendidikan Agama Islam di sekolah / madrasah bertujuan untuk menumbuhkan dan meningkatkan keimanan melalui pemberian dan pemupukan pengetahuan, penghayatan, pengamalan serta pengalaman peserta didik tentang agama Islam sehingga menjadi Manusia muslim yang terus berkembang dalam hal keimanan, ketaqwaan, berbangsa dan bernegara, serta untuk dapat melanjutkan pada jenjang pendidikan yang lebih tinggi. ${ }^{14}$

Tujuan Pendidikan Agama Islam ialah pembentukan kepribadian yang seluruh aspeknya dijiwai oleh ajaran Islam. Orang yang berkepribadian muslim dalam Al-Qur'an disebut "muttaqien". Untuk mencapai tujuan Pendidikan Agama Islam ini, membutuhkan suatu program pembelajaran yang formal yang mempunyai tujuan yang jelas dan konkret. Pembelajaran formal adalah suatu pembelajaran yang diorganisasi segala variabel pembelajarannya; seperti tujuan, cara, alat, waktu, tempat, dan evaluasi untuk mencapai tujuan tersebut. Dengan demikian dapatlah dipahami bahwa tujuan pendidikan agama Islam adalah sama dengan tujuan Manusia diciptakan, yakni untuk berbakti kepada Allah SWT. Dengan kata lain untuk membentuk manusia yang memahami, meyakini, dan mengamalkan ajaran-ajaran agama Islam. ${ }^{15}$ Pendidikan akhlak dalam ajaran Islam merupakan salah satu pokok penting yang harus diajarkan, supaya umatnya mempunyai akhlak yang mulia dan dapat melaksanakannya dalam kehidupan sehari-hari. Sebagaimana yang telah dicontohkan oleh Nabi Muhammad S.A.W.

Dari rumusan tujuan PAI tersebut di atas, dapat diambil pengertian bahwa pada dasarnya ada titik penekanan yang amat esensial dalam PAI. Titik penekanan tersebut lebih merupakan sebuah rangkaian filosofis di Mana harapan dari proses pembelajaran PAI adalah Manusia beriman dah berakhlak. Dikatakan demikian, karena seperti yang telah disinggung sebelumnya Pendidikan Agama Islam (PAI) adalah sebuah bentuk usaha sadar yang terncana dan memiliki hubungan erat dengan perubahan dalam masyarakat. Jadi sebenarnya antara beriman dan berakhlak merupakan sesuatu yang tidak dapat terpisah.

Adapun yang perlu dijadikan kajian ini adalah masalah tahapan proses mewujudkan tujuan tersebut, seiring dengan terjadinya kenakalan siswa di

13 Abd. Majid dan Dian Andayani, Pendidikan Agama Islam Berbasis Kompetensi; Konsep dan Implementasi Kurikulum 2004 (Bandung: Rosda Karya, 2004), 134.

14 Majid dan Andayani, Pendidikan Agama Islam Berbasis Kompetensi, 135.

15 Muhammad (Ed), Re-formulasi Rancangan Pembelajaran Pendidikan Agama Islam (Jakarta: Nur Insani, 2003), 73. 
sekolah. Guna mewujudkan hal tersebut, proses pendidikan agama Islam yang dilalui dan dialami oleh siswa di sekolah hendaknya dimulai dari tahapan kognisi, yakni pengetahuan dan pemahaman siswa terhadap ajaran dan nilai-nilai yang terkandung dalam ajaran Islam. Selanjutnya setelah siswa mampu memahami, maka dilanjutkan kepada tahapan afeksi, yakni proses internalisasi ajaran dan nilai agama ke dalam diri siswa, dalam arti menghayati dan meyakininya. Dari tahapan afeksi diharapkan dapat tumbuh dalam diri siswa motivasi untuk mengamalkan dan merealisasikan materi-materi PAI (psikomotor).

\section{Kenakalan Siswa; Suatu Kasus}

Siswa sebagai generasi muda yang akan mewarisi dan meneruskan cita-cita perjuangan bangsa dan negara. Baik dan buruknya suatu bangsa yang akan datang sepenuhnya tergantung kepada baik dan buruknya generasi muda di masa datang. Dapat dibayangkan bagaimana masa depan suatu bangsa yang apabila generasi mudanya mengalami dekadensi moral. Oleh karena itu patutlah menjadi bahan perhatian dan tanggung jawab orang tua, pendidik, masyarakat dan pemerintah dalam menanggulangi kenakalan siswa serta mencari alternative pemecahannya.

Di dalam menentukan nakal dan tidaknya tingkah laku seseorang terdapat perbedaan pandangan dikalangan masyarakat. Hal ini disebabkan karena perbedaan kondisi sosio cultural dimana seseorang tersebut tinggal. B. Simanjuntak, memberikan pengertian suatu perbuatan itu disebut nakal (delinquent). Apabila perbuatan tersebut bertentangan dengan norma-norma yang ada di masyarakat dimana ia tinggal, atau dapat dikatakan nakal itu adalah suatu perbuatan yang anti social dimana didalamnya terkandung unsur-unsur anti normatif. ${ }^{16}$

Kusumanto, menyatakan bahwa nakal adalah tingkah laku individu yang bertentangan dengan syarat-syarat dan pendapat umum yang dianggap sebagai eksiptabel dan baik oleh suatu lingkungan atau hukum yang berlaku di suatu masyarakat yang berkebudayaan tertentu. ${ }^{17}$ Bimo Walgito mengatakan bahwa nakal ialah "Tiap perbuatan apabila dilakukan oleh seorang dewasa, maka perbuatan itu adalah kejahatan. Jadi ialah perbuatan yang melawan hukum yang dilakukan oleh anak, khususnya anak siswa. ${ }^{18}$

Secara etimologi kenakalan siswa dapat diartikan merupakan suatu penyimpangan tingkah laku yang dilakukan oleh siswa sehingga mengganggu

\footnotetext{
16 B. Simanjutak, Pengantar Kriminologi dan Sosiologi (Bandung: Tarsito, 1977), 295.

17 Saifudin Sastra Wijaya, Beberapa Permasalahan Tentang Remaja (Bandung: Karya Nusantara,1975), 26.

${ }^{18}$ Bimo Walgito, Kenakalan Remaja (Bandung: Karya Nusantara, 1982), 2.
}

Jurnal Pendidikan Agama Islam

Volume 4 Nomor 2 Nopember 2016

ISSN(p) 2089-1946\& ISSN(e) 2527-4511

Hal. 302 - 314 
aktivitas ketentraman diri sendiri dan orang lain.19 Menurut Zakiah Daradjat kenakalan siswa adalah perbuatan-perbuatan yang mengganggu ketenangan serta kepentingan orang lain dan terkadang diri sendiri. ${ }^{20}$ Setiap tindakan kenakalan siswa betapapun kecilnya jika tidak mendapatkan penjelasan, teguran, serta controlling untuk memperbaikinya, akan mengakibatkan seseorang akan terlanjur melakukan yang lebih berbahaya lagi sehingga dapat dikategorikan sebagai tindakan kejahatan.

Sementara, jika dikaji lebih dalam lagi tentang sebab-sebab yang mendorong siswa menjadi delinquent (siswa nakal) pada dasarnya berasal dari tiga sumber utama, yaitu : pertama, keadaan keluarga. Keadaan anak sebagian besar berada dalam lingkungan keluarga, dan didalam keluargalah anak mendapatkan pendidikan yang pertama kali. Dengan demikian keluarga mempunyai pengaruh yang sangat terhadap perkembangan anak siswa. Keadaan keluarga dapat dibagi menjadi 2 yaitu keluarga normal dan keluarga yang tidak normal yang mencakup broken home dan quasi broken home (broken home semu). Dari keduanya akan timbul kekurangan-kekurangan yang dirasakan oleh anak yaitu anak kurang mendapat perhatian dan kasih sayang dari orang tua, tidak adanya kesatuan norma dalam keluarga, anak tidak pernah mendapatkan latihan fisik dan mental yang dibutuhkan dalam kehidupannya dan kebutuhan fisik dan psikis tidak terpenuhi dengan baik oleh anak siswa. Jika dikaji bersama dan lebih lanjut peran keluarga yang berkaitan dengan kenakalan siswa dikarenakan sikap dan tingkah laku orang tua yang tidak mendidik atau kurang mendidik.

Kedua, keadaan sekolah. Sekolah sebagai lembaga pendidikan tentunya yang diharapkan ialah pengaruh yang positif terhadap perkembangan jiwa siswa sebagaimana dengan keluarga, sekolah juga menanamkan nilai-nilai atau normanorma dalam hidup bermasyarakat disamping mengajarkan berbagai ketrampilan dan keilmuan kepada siswanya. Faktor yang berpengaruh di sekolah bukan hanya guru serta sarana dan prasarana pendidikan saja. Lingkungan antar teman juga sangat berpengaruh terhadap perkembangan jiwa siswa. Anak-anak yang memasuki sekolah membawa watak serta bakat yang berbeda. Di samping itu juga anak berasal dari kondisi keluarga dan lingkungan yang berbeda.

Ketiga, keadaan masyarakat. Masyarakat sebagai tempat pendidikan yang terluas dan sekaligus banyak menawarkan berbagai pilihan terutama dengan maju dan pesatnya teknologi komunikasi dan informasi yang menimbulkan berbagai perubahan baik positif atau negative bagi siswa. Hal yang terakhir inilah yang

${ }^{19}$ Hasan Basri, Remaja Berkualitas,Problematika Remaja dan Solusinya (Jogjakarta: Pustaka Pelajar, 1996), 13.

20 Zakiah Darajat, Kesehatan Mental (Jakarta: Haji Masagung, 1990), cet VI, 113. 
merupakan salah satu penyebab terjadinya delinquent pada siswa karena dengan majunya teknologi dan cepatnya informasi baik yang positif maupun yang negatif.

Untuk menentukan faktor yang paling dominan, menyesuaikan pada kondisi siswa secara kontekstual. Namun secara objektif dapat digeneralisir bahwa perkembangan dan pertumbuhan siswa dikendalikan oleh proses kematangan yang terjadi didalam dirinya, seperti faktor kematangan, sehingga dengan demikian faktor kebudayaan dan lingkungan sosial kurang diperhatikan. Di sisi lain, kematangan biologis kurang memberikan pengaruh terhadap perkembangan remaja. Pandangan biologis sebagai dasar yang menentukan perkembangan remaja kurang memuaskan. Sudah jelas masa tersebut timbul banyak persoalan dan pertentangan. Persoalan yang tidak dapat dielakkan sesuai dengan corak kebudayaan.

Dalam kaitannya dengan hal tersebut ada beberapa pendapat aliran yang membicarakan tentang faktor manakah yang mendominasi dalam perkembangan seorang individu ada tiga aliran yaitu: pertama, nativisme, berpendapat bahwa nasib anak itu sebagian besar berpusat pada pembawaannya, sedangkan pengaruh lingkungan hidupnya hanya sedikit saja. Baik buruknya perkembangan anak sepenuhnya tergantung pada pembawaannya. Kedua, empirisme, berpendapat bahwa perkembangan anak itu sepenuhnya tergantung pada fakor lingkungan, sedangkan faktor bakat tidak ada pengaruhnya. Ketiga, konvergensi21, berpendapat bahwa perkembangan itu adalah hasil kerja sama antara kedua faktor yaitu pembawaan dan lingkungan, faktor dasar dan faktor ajar.

Dari beberapa pendapat tersebut di atas, dapat disimpulkan bahwa proses perkembangan individu dipengaruhi oleh faktor eksternal yaitu faktor lingkungan serta juga dipengaruhi oleh faktor internal yang berupa pembawaan (hereditas). Tercapai atau tidaknya tugas-tugas perkembangan di atas tergantung oleh 3 faktor yaitu: kematangan fisik, desakan dari masyarakat dan motivasi dari individu yang bersangkutan.

Maka, siswa yang nakal adalah siswa yang memiliki masalah ketidakmampuan untuk menyesuaikan diri dengan lingkungannya sehingga ia akan melakukan perbuatan-perbuatan yang tidak wajar, padahal sesungguhnya remaja yang nakal adalah manusia yang biasa seperti kita, ia juga memiliki bentuk dasar manusia yakni makhluk yang baik dan selalu memihak pada kebenaran. Oleh sebab itu, maka dapat dikatakan bahwa siswa yang nakal atau yang menyimpang, yang hidup secara tidak wajar sebenarnya adalah bukan karena fitrahnya, akan tetapi ada sebab-sebab yang melatar-belakanginya atau mendorongnya untuk

\footnotetext{
${ }^{21}$ Menurut aliran ini, anak pada waktu dilahirkan telah membawa potensi yang akan berkembang, maka lingkungan yang memungkinkan mengembangkan potensi-potensi tersebut.
} 
berbuat nakal yakni faktor intern dan ekstern. Sehingga dengan demikian, maka perlu adanya proses internalisasi pendidikan agama Islam yang berkelanjutan.

\section{Bentuk-bentuk Kenakalan Siswa di MTs Hasanah Surabaya}

Setiap tindakan kenakalan siswa betapapun kecilnya jika tidak mendapatkan penjelasan, teguran, serta kontroling untuk memperbaikinya, akan mengakibatkan seseorang akan terlanjur melakukan yang lebih berbahaya lagi sehingga dapat dikategorikan sebagai tindakan kejahatan. Kenakalan siswa sebagai suatu kondisi yang kurang menyenangkan dalam kehidupan sosial banyak jenisnya. Dan berdasarkan hasil wawancara dengan Bapak Dodik Susilo selaku Guru BP Di MTs Hasanah Surabaya, ada tiga macam jenis kenakalan siswa di MTs Hasanah, yaitu:22 Pertama, Kenakalan siswa yang menyentuh psikologis, seperti tercemarnya nama baik seseorang, harga diri serta martabat seseorang karena fitnah. Kedua, kenakalan siswa yang menyentuh atau berkaitan dengan masalah material atau kebendaan, seperti pengerusakan gedung. Ketiga, kenakalan siswa yang menyentuh norma-norma agama, sosial, atau adat yang berlaku dalam masyarakat, seperti mencuri, tawuran atau melakukan hubungan seks di luar nikah.

Dari observasi lapangan, interview, dan dokumentasi dari Kepala Sekolah dan guru BK di MTs Hasanah Surabaya. Di lihat dari nilai-nilai keislaman dan hukum yang berlaku maka bentuk kenakalan siswa di antaranya: menggoda lawan jenis, suka berkelahi, bolos sekolah, berkata kotor, mengolok-olok sesama teman di dalam kelas sehingga memicu pertengkaran, dan mengakibatkan kegaduhan di dalam lingkungan sekolah dan kurang disiplin di dalam mematuhi aturan yang sudah di terapkan oleh pihak sekolah. Hal ini diperjelas oleh keterangan Ibu Khairun Nisa' SS, M.Pd, selaku kepala MTs Hasanah:

"Tindak kenakalan memang tidak pernah lepas dari kehidupan siswa hal ini terjadi di Sekolah MTs Hasanah Surabaya yang mana siswa-siswa tersebut sebagian termasuk siswa yang delenquen. Setiap tindak kenakalan yang dilakukan oleh siswa pasti ada faktor yang mendukung tindakan tersebut. Jadi setiap tindakan yang menyimpang tidak terlepas dari pengaruh faktor yang negative yang diterima oleh setiap individu siswa atau kelompok siswa." 23

Dari bentuk-bentuk kenakalan siswa di atas, Bapak Dodik Susilo mengatakan bahwa24:

${ }^{22}$ Hasil Wawancara dengan Bapak Dodik Susilo selaku Guru BP Di MTs Hasanah Surabaya, pada 29 Juli 2016.

23 Hasil Wawancara dengfan Ibu Khairun Nisa SS.M.Pd selaku Kepala Sekolah, pada 29 Juli 2016.

${ }^{24}$ Hasil Wawancara Dengan Bapak Dodik Susilo Guru BP MTs Hasanah Surabaya pada 19 Juli 2016. 
"Semua bentuk kenakalan itu merupakan bagian dari perilaku menyimpang yang kerap akan merugikan mereka sendiri. Oleh karena itu pihak sekolah, guru dan orang tua, wajib hukumnya mengerti dan peduli.." 25

Lebih lanjut beliau mengatakan:

“...Perkelahian antar pelajar kian semarak serta menyebar luas akan eksistensinya kemana-mana. hampir tidak ada satupun sudut kota yang tidak pernah terencana sebelumnya dan dalam skala kecil hingga ke taraf tawuran yang melibatkan antar pelajar dalam jumlah besar dan telah direncanakan sebelumnya.." 26

Siswa adalah mereka yang berusia 13-18 tahun. Pada usia tersebut, seseorang sudah melampaui masa kanak-kanak, namun masih belum cukup matang untuk dapat dikatakan dewasa. Ia berada pada masa transisi. Karena transisi itulah yang kerap banyak godaan untuk menuju matang. Di MTs Hasanah siswa cenderung menampakkan gejala (fenomena) ini dengan mengekspresikannya melalui coba-coba ingin merasakan dan melakukan analisis serta telaah keilmuan. Adanya perkembangan keingintahuan ini, selain banyak bertanya siswa juga banyak memberikan kritik baik dalam perkataan maupun prilaku.

Sedangkan faktor yang mendukung terciptanya siswa-siswa yang delenquen di MTs Hasanah Surabaya bermacam-macam ragamnya. Adanya faktor-faktor tersebut adalah dari hasil observasi dan interview didapat bahwa yang mempengaruhi para siswa setempat adalah: ekonomi yang kurang, perhatian dan kontrol dari keluarga yang kurang, media masa, cetak, dan elektronik, pergaulan yang negative, pengaruh lingkungan sekolah yang negative, rasa ingin tau dan mencoba, dan kurang faham terhadap nilai-nilai keagamaan. ${ }^{27}$

Sementara, data dari observasi didapatkan bahwa faktor yang mempengaruhi kenalakn siswa adalah: perhatian orang tua terhadap anak kurang, kurangnya komunikasi dalam keluarga, pengaruh teman dan pergaulan, ekonomi keluarga yang rendah, pemahaman dan minat beragama yang kurang, dan kesadaran individu siswa kurang.

"Sebenarnya di antara penyebab kenakalan anak-anak di sini yang paling berdampak negatif adalah kurang perhatian orang tua. Banyak siswa nakal disebabkan kedua orang tuanya pergi bekerja keluar negeri, sehingga perhatian orang tua kepada siswa menjadi kurang. Di samping itu hal-hal yang bisa mempengaruhi siswa di sekolah di antaranya adalah teman sepermainan. Padahal

${ }^{25}$ Hasil wawancara Dengan Bapak Dodik Susilo Guru BP MTs Hasanah Surabaya pada 19 Juli 2016.

${ }^{26}$ Hasil wawancara Dengan Bapak Dodik Susilo Guru BP MTs Hasanah pada 01 November 2016.

${ }^{27}$ Hasil Wawancara dengan Bapak Misbachul Chamim S.Pd selaku guru agama MTs Hasanah, pada 9 Agustus 2016.

Jurnal Pendidikan Agama Islam

Volume 4 Nomor 2 Nopember 2016

ISSN(p) 2089-1946\& ISSN(e) 2527-4511

Hal. 306 - 314 
peraturan di sekolah sudah ketat tetapi siswa masih bisa mencari kelemahan dari peraturan yang sudah dibuat." ${ }^{28}$

Lebih lanjut, ketika penulis mewawancarai salah seorang siswa di sekolah ini, salah satu penyebab kenakalan siswa di antaranya disebabkan karena pengaruh lingkungan keluarga yang tidak harmonis, seperti pernyataanya di bawah ini:

“..Kedua orang tua saya bercerai, Bapak menikah lagi dan tidak merawat keluarga saya. Sedangkan Ibu bekerja ke Arab, sehingga di rumah saya tinggal dengan nenek.." 29

Setelah itu, penulis melakukan wawancara dengan Muhammad Anas salah seorang siswa kelas IX yang sering membolos sekolah dan suka mengamen di jalan raya :

"Saya suka mengamen di jalanan karena untuk menambah jatah uang jajan saya dikarenakan yang dikasih orang tua tidak cukup untuk bermain internet dan Play Station. Walaupun saya pernah tertangkap oleh SATPOL PP saya merasa biasa-biasa saja karena walaupun saya tertangkap orang tua saya pasti datang dan membebaskan saya, dan alasan mengapa saya sering bolos sekolah karena saya sering diolok-olok oleh teman teman satu kelas saya. Nah, daripada saya di sekolahan menjadi bahan tertawaan mending saya membolos dengan bermain internet dan Play Station nanti kalau sudah waktunya pulang saya ikut pulang juga karena orang tua saya tidak mungkin tahu kalau saya tidak sekolah, tapi saya akhir akhir ini merasa apa yang saya lakukan itu salah dan saya harus berhenti karena kalau saya seperti itu terus tidak ada baiknya untuk saya karena saya selalu masuk kantor BP dan saya juga malu karena orang tua saya selalu dipanggil karena masalah saya, dan saya juga ingin berubah pak masak saya terus terusan seperti ini, karena saya kalau terus terusan begini nanti saya gak maju maju." ${ }^{30}$

Selanjutnya, penulis juga melakukan wawancara dengan Fajar Yudha Pratama Siswa kelas IX yang juga suka membolos :

“...Saya tidak suka membolos, tapi berhubung saya diajak oleh teman teman yang lain jadi terpaksa saya juga ikut membolos, walaupun saya juga tahu pasti dihukum kalau ketahuan Guru BP saya ikut saja nanti saya buat alasan sakit jadi absen saya bukan Alpa tetapi izin tidak masuk, tapi meskipun begitu saya juga merasa agak menyesal karena semakin sering saya tidak masuk sekolah saya bisa ketinggalan pelajaran yang nanti nilai saya akan jeblok, karena cita cita saya ingin jadi

${ }^{28}$ Hasil wawancara dengan Bapak Dodik Susilo S.Pd Guru BP MTs Hasanah Surabaya, pada 19 Agustus 2013.

${ }^{29}$ Hasil wawancara dengan Ahmad Sofiuddun, siswa kelas IX, pada 19 Agustus 2013.

${ }^{30}$ Hasil wawancara dengan Muhammad Anas Siswa kelas IX MTs Hasanah Surabaya pada 17 Juli 2016. 
pengusaha pak kan kalau pengusaha harus belajar mulai kecil biar tambah pintar dan pengetahuan..."31

Selain melakukan wawancara dengan Siswa MTs Hasanah Surabaya Penulis juga melakukan wawancara dengan orang tua siswa dengan memanggil orang tua dan visit home.

Diungkapkan oleh Solikin, orang tua dari Opi Antoni yang mengatakan bahwa :

“.. sebenarnya saya juga tidak ingin anak saya membantu saya untuk bekerja pak. Tapi bagaimana lagi pak, anak saya berkemauan begitu dan saya pikir juga asalkan tidak mengganggu jam belajarnya saya biarkan saja dan untuk yang keluar malam saya juga sudah melarang mas tapi anaknya tetap saja berangkat pak kalau saya larang takutnya dia malah berontak pak, karena selama ini walaupun seperti itu nilainya juga tidak merosot pak dan kalau sekolah juga tidak malas “32

Begitu juga yang diungkapkan oleh Ibu To'ani orang tua Muhammad Anas yang mengatakan :

" saya sudah tidak kurang-kurang pak untuk memberi tahu anak saya pak tapi dia selalu bandel, pamit sekolah ternyata tidak sekolah pak, tapi akhir akhir ini alhamdulillah pak sudah sadar pak karena sering belajar agama dan habis di panggil oleh Guru BP nya ".33

Dari wawancara di atas, penulis menyimpulkan bahwa faktor kenakalan siswa paling dominan dimulai dari diri sendiri dan lingkungan sekitarnya yang mendukung untuk melakukan hal itu. Seperti halnya Muhammad Anas yang tidak sungkan ketika melakukan kegiatan mengamen di jalan raya pada malam hari. Padahal, tidak semestinya sebagai seorang siswa yang masih duduk di bangku MTs melakukan hal yang seperti itu. Namun, dari keluarga sepertinya sudah mengetahui hal tersebut namun tidak ada perlakuan atau tindakan untuk memberikan efek jera agar anak tersebut tidak melakukan hal yang seperti itu yaitu mengamen di jalan raya.

Dan dari teman sekolahnya juga terlalu sering untuk mengolok olok terhadap apa yang dilakukan leh rekannya. Karena terlalu seringnya dalam keseharian di sekolah memanggil nama temannya dengan sebutan yang tidak semestinya dengan julukan atau nama orang tuanya yang dilakukan oleh Opi Antoni kepada sesama teman di sekolahnya bisa memicu sebuah pertengkaran karena di antara salah satunya ada yang tersingung jika dipanggil dengan panggilan yang tidak semestinya. Terlepas dari itu semua, ketiga siswa tersebut

\footnotetext{
${ }^{31}$ Hasil wawancara dengan Fajar Yudha Pratama Siswa Kelas IX MTs Hasanah Suraaya, pada 18 Juli 2016.

32 Hasil Wawancara Dengan Bapak Solikin Orang Tua Opi Antoni, pada 20 Juli 2016.

33 Hasil Wawancara Dengan Ibu To'ani Orang Tua Muhammad Anas, pada 20 Juli 2016
}

Jurnal Pendidikan Agama Islam

Volume 4 Nomor 2 Nopember 2016

ISSN(p) 2089-1946\& ISSN(e) 2527-4511

Hal. 308 - 314 
masih memiliki tanggung jawab akan posisi mereka yaitu sebagai siswa, sebagai murid yang harus melakukan tugasnya demi mencapai masa depan yang lebih baik.

\section{E. Reinternalisasi Pendidikan Agama Islam; Upaya Penanggulangan Kenakalan Siswa di MTs Hasanah Surabaya}

Dalam Pendidikan Islam, tujuan pokok dan terutama adalah mendidik budi pekerti dan pendidikan jiwa. ${ }^{34}$ Tujuan dari pendidikan adalah taqarrub kepada Allah dan kesempurnaan manusia untuk mencapai kebahagiaan dunia dan akhirat. Dari tujuan pendidikan di atas, bisa dikatakan bahwa tujuan pendidikan nasional dari waktu ke waktu selalu bermuara pada terbentuknya manusia yang susila atau berbudi pekerti luhur.

Siswa di MTs Hasanah Surabaya mempunyai tingkat perkembangan kepribadian dan sosial yang berada dimana pada masa transisi dari anak-anak ke remaja. Seperti yang kita ketahui, asa remaja ${ }^{35}$ di sekolah menengah menghadapi beberapa aspek utama perkembangan kejiwaan anak yaitu berkaitan dengan status sosial dan keragaman kemampuan kognisi yang akan mempengaruhi proses pendidikan di sekolah. Latar belakang sosial seperti keluarga, ekonomi masing-masing anak yang berbeda akan memberikan pengaruh pada prestasi anak di MTs Hasanah Surabaya ini.

Menurut Ibu Khairun Nisa', kewajiban untuk membina tidak cukup diserahkan kepada guru saja, tetapi keluarga dan lingkungan masyarakat juga mempunyai peranan yang sama. Sebagaimana telah sama-sama diketahui, bahwa paling tidak terdapat tiga lingkungan pendidikan yang berpengaruh terhadap pembentukan kualitas dan kepribadian siswa, yakni lingkungan keluarga, sekolah dan masyarakat. ${ }^{36}$

Kondisi yang harmonis dan sinergis di antara ketiganya dan merupakan satu kesatuan yang terintegrasi. Apa yang diyakini baik dirumah, baik pula di sekolah dan masyarakat. Demikian pula hanya ketidakbaikan, semuanya memberikan persepsi dan perlakuan yang sama. Tetapi dalam kenyataannya tidaklah selalu demikian. Pendidikan mempunyai peranan penting dalam

\footnotetext{
34 M.Athiyah al-Abrasyi, Dasar-Dasar Pokok Pendidikan Islam (Jakarta: Bulan Bintang, 1993), 1.

35 Dengan kondisi perkembangan remaja pada masa ini, maka proses pendidikan memerlukan kondisi kondusif agar perkembangan kemampuan kognitif, afektif dan psikomotorik remaja dapat mencapai tujuan yang diharapkan. Generasi muda adalah sebagai generasi penerus yang akan menggantikan estafet generasi orang tua, sudah barang tentu harus dibina dengan sungguh-sungguh agar mereka menjadi generasi penerus yang bertanggung jawab dan bermoral.

${ }^{36}$ Hasil Wawancara dengfan Ibu Khairun Nisa SS.M.Pd selaku Kepala Sekolah, pada September 2016.
} 
pembinaan dan pengembangan anak, terutama berkenaan dengan penanaman nilai-nilai keagamaan semenjak dini.

“.Setiap siswa mempunyai keragaman dalam hal kecakapan maupun kepribadian. Dalam proses belajar mengajar, karakteristik para siswa sangat perlu diperhitungkan lantaran dapat mempengaruhi jalannya proses dan hasil pembelajaran siswa yang bersangkutan." 37

Maka menurut pendapat Bapak Dodik Susilo di atas, adalah penting sekali bagi guru mengenal dan memahami siswa dengan seksama. Tujuannya agar guru dapat menentukan dengan seksama bahan-bahan yang akan diberikan, menggunakan prosedur (strategi dan metode) mengajar yang serasi, serta mengadakan diagnosis atas kesulitan belajar yang dialami siswa, membantu siswa mengatasi masalah pribadi dan sosial, memberikan bimbingan, menilai hasil belajar dan kemajuan belajar siswa, dan kegiatan-kegiatan guru lainnya yang bertalian dengan individu siswa

Selama ini, penerapan Pendidikan Agama Islam (PAI) selama ini kurang menyentuh substansi dari PAI itu sendiri sehingga sering mengalami kesulitan dalam pengaplikasiannya. Demikian pula yang terjadi di MTs Hasanah Surabaya. Maka, dilakukanlah beberapa upaya untuk menangani kenakalan siswa tersebut. Upaya-upaya tersebut yaitu secara preventif, represif dan kuratif. Preventif yaitu suatu usaha untuk menghindari kenakalan, jauh sebelum kenakalan itu terjadi dan terlaksana atau agar kenakalan itu tidak terjadi. Diharapkan dari usaha ini akan dapat mengurangi timbulnya kenakalan-kenakalan baru atau setidak-tidaknya akan bisa memperkecil jumlah pelakunya.

Usaha yang dianggap cukup berhasil dalam hal ini adalah mengadakan pendekatan dengan orang tua atau wali siswa. Sedangkan cara represif yaitu usaha atau tindakan untuk menindak dan menahan kenakalan siswa sedini mungkin atau menghalangi peristiwa yang lebih hebat.

“...Usaha represif dapat diwujudkan dengan jalan mengadakan tindakan atau hukuman kepada anak siswa bermasalah / nakal terhadap setiap pelanggaran yang ia lakukan yang mana hukuman itu berbentuk mendidik dan menolong agar mereka menyadari akan perbuatannya dan kembali mempunyai harga diri, dan usaha yang cukup berhasil adalah memberi hukuman yang mendidik dan memberikan tugas.." ${ }^{\prime 3}$

Cara kuratif adalah usaha untuk menyembuhkan atau memperbaiki apabila kenakalan siswa itu sudah terjadi. Usaha yang dianggap cukup berhasil adalah silaturrahim ke rumah siswa. Selain itu juga dengan memberikan teladan yang

37 Hasil wawancara Dengan Bapak Dodik Susilo Guru BP MTs Hasanah, pada 04 November 2016.

38 Hasil wawancara dengan Bapak Dodik Susilo Guru BP MTs Hasanah Surabaya, pada 18 Juli 2016. 
baik kepada siswa juga dapat mempengaruhi siswa dalam berperilaku. Sehingga dapat meminimalisir kenakalan siswa di MTs Hasanah. Sebagaimana diungkapkan oleh Ibu Khairun Nisa SS. M.Pd Selaku Kepala Sekolah MTs Hasanah Surabaya

“..Salah satu metode yang paling efektif dalam penanaman nilai-nilai pada siswa adalah dengan cara memberikan teladan yang baik pada siswa. Sebagaimana yang telah dilakukan oleh Rasulullah SAW, ketika menyebarkan ajaran Islam untuk pertama kalinya..."39

Metode (Teladan yang baik) yang dilakukan oleh Rasulullah harus dicontoh oleh pendidik dalam proses penanaman nilai-nilai ajaran Islam pada siswa. Metode ini merupakan penunjang dari metode-metode yang telah disebutkan sebelumnya. Tanpa adanya contoh yang baik dari seorang pendidik maka siswa akan enggan melaksanakan apa-apa yang telah disampaikan oleh pendidik kepadanya.

Hal ini sesuai dengan Nabi Muhammad yang senantiasa menuntun dan memberikan contoh atau suri tauladan yang benar dalam akhlak dan kegiatan yang dilakukan. Keagungan dan kemuliaan akhlak Rasulullah bukan saja mendapat pengakuan dari sesama manusia tetapi juga Allah SWT memujinya dengan firmannya:
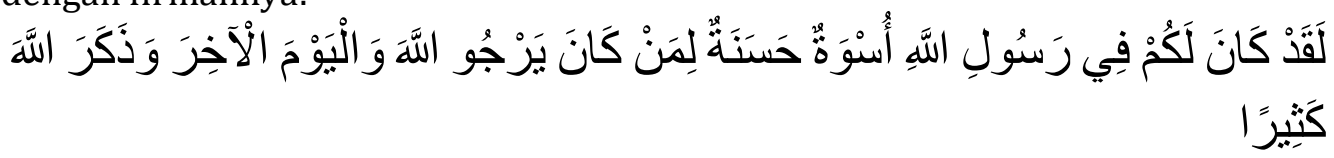

"Sesungguhnya telah ada pada (diri) Rasulullah itu suri tauladan yang baik bagimu (yaitu) bagi orang yang mengharap (rahmat) Allah dan (kedatangan) hari kiamat dan banyak menyebut Allah" 40 (Q. S. al-Ahzab:21)

Metode teladan yang baik yang dilakukan oleh Rasulullah harus dicontoh oleh pendidik dalam proses penanaman nilai-nilai ajaran Islam pada siswa. Metode ini merupakan penunjang dari metode-metode yang telah disebutkan sebelumnya. Tanpa adanya contoh yang baik dari seorang pendidik, maka siswa akan enggan melaksanakan apa-apa yang telah disampaikan oleh pendidik kepadanya.

Senetara itu, beberapa siswa menjelaskan sekian banyak faktor yang dapat menyebabkan munculnya kenakalan siswa seperti halnya kasus penyimpangan seksual. Namun, dari siswa-siswa tersebut mengaku setelah mereka mendapatkan pelajaran pendidikan agama Islam di sekolah mereka dalam hal berperilaku dan menjaga etitut untuk tidak melakukan kenakalan siswa lebih terkontrol. Mereka mengaku keinginan dari hati mereka dengan mengingat norma-norma agama

${ }^{39}$ Hasil Wawancara Dengan Ibu Khairun Nisa SS M.Pd selaku kepala MTs Hasanah Surabaya, pada 19 Juli 2016

${ }^{40}$ Departemen Agama RI, Al-Qur'an Dan Terjemahnya (Bandung: Diponegoro, 2000), 336. 
yang di ajarkan serta selalu mengingat Allah SWT dapat membantu untuk menjauhkan keinginan-keinginan negatif yang timbul dalam diri mereka. Dibantu dengan pemantauan serta pendekatan personal yang dilakukan oleh guru agama, mereka semakin nyaman dan semakin terkontrol dalam bertingkah laku.

"Semua guru agama telah mengajarkan pendidikan agama Islam baik teori ataupun praktek seperti sholat, puasa dan amal ibadah yang dapat menjauhkan anak-anak dari tindakan amoral. Selain itu, pihak sekolah juga telah berkomunikasi dengan para wali murid. Namun, yang terpenting adalah pendekatan dan control yang harus dilakukan para guru agama dan orang tua "Si Anak". Dan hal tersebut harus diiringi dengan teladan yang baik dari seluruh elemen baik di sekolah maupun di lingkungan masyarakat." 41

Setelah melihat serta memperhatikan proses pembelajaran pendidikan agama Islam di MTs Hasanah Surabaya yang tidak hanya memperhatikan aspek kurikulum yang ditetapkan oleh pemerintah. Namun juga melalui pendekatanpendekatan emosional guru kepada setiap individu yang bermasalah atau dinilai kurang baik dalam bertingkah laku menghasilkan efek baik pada mutu akhlak siswa itu sendiri, yakni dengan berkurangnya kasus-kasus penyimpangan seksual siswa. Seperti halnya kasus video porno yang pernah mewabah di sekolah ini sudah mulai tidak terlihat lagi. Moral-moral siswa dalam bertingkah laku semakin tertata karena kebiasaan-kebiasaan yang diterapkan di sekolah tersebut. Didukung dengan adanya aturan-aturan yang diberlakukan untuk menyempurnakan akhlak siswa tersebut.

Menurut sudut pandang penulis, setelah melakukan observasi, wawancara, serta metode dokumentasi. Ditemukan keefektifitasan pendidikan agama Islam dalam mengentas problem penyimpangan seksual di MTs Hasanah Surabaya. Dengan adanya peningkatan mutu akhlak siswa di setiap tahunnya, serta pengakuan para siswa tentang keefektifitasan pendidikan agama Islam yang mereka dapatkan hal ini membuktikan upaya guru dalam mengentas kenakalan siswa, telah bisa dikatakan berhasil.

\section{F. Kesimpulan}

Sebagai bagian akhir artikel ini, penulis menguraikan sebuah kesimpulan bahwa ada tiga macam jenis kenakalan siswa di MTs Hasanah, yaitu: Pertama, kenakalan psikologis, seperti tercemarnya nama baik seseorang, harga diri serta martabat seseorang karena fitnah. Kedua, kenakalan materialis, seperti pengerusakan gedung. Ketiga, kenakalan normatif, seperti mencuri, tawuran atau melakukan hubungan seks di luar nikah. Faktor penyebab timbulnya berbagai

${ }^{41}$ Hasil Wawancara dengan Ibu Khairun Nisa SS. M.Pd selaku Kepala MTs Hasanah, pada 21 Desember 2016. 
jenis kenakalan siswa berasal dari ketiga lingkungan yaitu keluarga, sekolah dan masyarakat. Dari kenekalan-kenakalan siswa tersebut, maka MTs Hasanah melakukan beberapa hal dalam menanggulanginya dengan tiga cara yaitu: pertama, preventif. Ini yang dianggap cukup berhasil adalah mengadakan pendekatan dengan orang tua atau wali siswa. Kedua, represif. Cara represif cukup berhasil adalah memberi hukuman yang mendidik dan tugas. Ketiga, kuratif. Cara ini cukup berhasil adanya silaturrahim ke rumah siswa. Di sisi lain berapa solusi tersebut harus diiringi dengan internalisasi Pendidikan Agama Islam dengan baik, baik melalui ceramah (nasehat), diskusi, dan teladan yang baik dari semua pihak. Dari observasi, wawancara, serta metode dokumentasi, ditemukan efektfitas Pendidikan Agama Islam dalam mengentas problem kenakalan siswa di MTs Hasanah Surabaya. Dengan adanya peninggatan mutu akhlak siswa baik di dalam kelas, di luar ataupun di lingkungan masyarakat, maka bisa dikatakan upaya reinternalisasi Pendidikan Agama Islam tidak hanya memberikan pengetahuan, tapi juga memberikan nilai.

\section{G. Referensi}

Abrasyi (al), M.Athiyah. Dasar-Dasar Pokok Pendidikan Islam (Jakarta: Bulan Bintang, 1993), 1.

Arifin, H.M. Pedoman Bimbingan dan Penyuluhan Agama. Jakarta: Golden Terayon, 1987.

Basri, Hasan. Remaja Berkualitas,Problematika Remaja dan Solusinya. Jogjakarta: Pustaka Pelajar, 1996.

Darajat, Zakiah. Kesehatan Mental. Jakarta: Haji Masagung, 1990. Siswa; Harapan dan Tantangan, Jakarta : Ruhama, 1994.

Departemen Agama RI. Al-Qur'an dan Terjemahnya. Bandung: Diponegoro, 2000.

Ghony, M. Djunaidi. “Pemikiran Al-Ghazali Tentang Pendidikan”. Jurnal El-Hikmah, Fakultas Tarbiyah UIN Malang. Vol. 3 No.2. Januari 2006.

Hafidhuddin, Didin. Membentuk Pribadi Qur'ani. Bandung : Harakah, 2002.

Majid, Abdul dan Andayani, Dian. Pendidikan Agama Islam Berbasis Kompetensi (Konsep dan Implementasi Kurikulum 2004. Bandung: Rosda Karya, 2004.

Muhammad (Ed). Re-Formulasi Rancangan Pembelajaran Pendidikan Agama Islam. Jakarta: Nur Insani, 2003.

Poerwadarwminta, WJS. Kamus Umum Bahasa Indonesia. Jakarta: Balai Pustaka, 1976.

Sarwono, Sarlito Wirawan. Psikologi Siswa. Jakarta : Raja Grafindo Persada, 1999. Simanjutak, B. Pengantar Kriminologi dan Sosiologi. Bandung: Tarsito, 1977. 
Muchammad Ainul Yaqin

Soma, Safari. Menanggulangi Remaja Kriminal, Islam Sebagai Alternatif. Bogor : Bintang Tsurayya, 1995.

Sunarto. Perkembangan Peserta Didik. Jakarta: Rineka Cipta, 1999.

Sutikno, "Pola Pendidikan Islam dalam Surat Luqman Ayat 12-19". Jurnal Pendidikan Agama Islam (JPAI) FTK UIN Sunan Ampel Surabaya, Vol. 1. No. 2 (2013).

Syirazi, Nashir Makarim. Gejolak Kaum Muda. Jakarta: Lentera, 1999.

UUSPN Nomor 20 Tahun 2003, BAB II,Pasal 3.

Walgito, Bimo. Kenakalan Remaja. Bandung: Karya Nusantara, 1982.

Wijaya, Saifudin Sastra. Beberapa Permasalahan Tentang Remaja. Bandung: Karya Nusantara, 1975.

Willis, Sofyan S. Siswa dan Masalahnya. Bandung : Alfabeta, 2005.

Yunus, Mahmud. Metodik Khusus Pendidikan Agama. Jakarta: Hidarkarya Agung, 1983.

Zuhairini. Filsafat Pendidikan Islam. Jakarta: Bumi Aksara, 1995.

http://surabaya-metropolis.com/serba-kota/gaya-hidup/kenakalan-remajagaya-hidup-menyimpang.html. Diakses pada 20 November 2016. 